\section{Rapid PCR-based Detection of Phytoplasmas from Infected Plants}

\author{
Yonghong Guo
}

Department of Plant Sciences, North Dakota State University, Fargo, ND 58105 and Upstate Biotechnology USA, Inc., Lake Placid, NY 12946

\section{Zong-Ming (Max) Cheng ${ }^{1}$}

Department of Plant Sciences and Landscape Systems, University of Tennessee, Knoxville, TN 37996-4500 and Department of Plant Sciences, North Dakota State University, Fargo, ND 58105

\section{James A. Walla \\ Department of Plant Pathology, North Dakota State University, Fargo, ND 58105}

Additional index words. DNA preparation, PCR amplification, periwinkle (Catharanthus roseus), green ash (Fraxinus pennsylvanica)

\begin{abstract}
Five simplified DNA preparation procedures for polymerase chain reaction (PCR) amplification were tested for detection of phytoplasmas from infected herbaceous and woody plants. Thin freehand cross-sections made from infected plant tissues and stored in acetone were used as sources for DNA preparation. The tissue sections were treated by: 1) grinding in sodium hydroxide; 2) sonicating in water; 3) microwaving in water; 4) boiling in sodium hydroxide; or 5) placing directly in PCR tube. PCR amplification was performed with a universal phytoplasma-specific primer pair in a reaction buffer containing $0.5 \%$ (v/v) Triton X-100, $1.5 \mathrm{~mm}$ magnesium chloride, and $10 \mathrm{~mm}$ Tris-HCl. All five procedures provided phytoplasmal template DNA for successful PCR amplification from infected herbaceous plants \{periwinkle [Catharanthus roseus (L.) G. Don (periwinkle)], carrot (Daucus carota $\mathrm{L}_{\text {.) }}$, maize (Zea mays $\left.\mathrm{L}_{\text {. }}\right)$, while the grinding, microwaving, and boiling procedures also allowed positive amplification from a woody plant [green ash (Fraxinus pennsylvanica Marsh.)]. The quality of the resulting DNA was adequate for subsequent identification of the aster yellows and ash yellows phytoplasmas through nested-PCR using phytoplasma group-specific primer pairs. These methods provide remarkable savings in labor and materials, making disease testing and indexing of plant materials much more attractive.
\end{abstract}

Phytoplasmas [formerly known as mycoplasma-like organisms (MLOs)] are a group of cell wall-less, nonculturable prokaryotes. These insect-transmitted, phloem-restricted microorganisms are associated with diseases in more than 300 species of higher plants worldwide, from cool temperate to tropical regions (Kirkpatrick, 1989). Conventional specific diagnosis of phytoplasmal infection requires pre-development of an antibody or DNA probe specific to phytoplasmas and is only moderately sensitive. If the diagnosis is negative, it is unknown whether it is due to a low titer of phytoplasmas in the plant tissue or due to a lack of infection. Polymerase chain

Received for publication 2 Mar. 2001. Accepted for publication 21 Dec. 2002. This research was supported by the grants from NDEPSCoR/NSF/ TRIC to Z.M.C. and USDA-NRICGP-1999-2510 to Z.M.C. and Y.H.G. We acknowledge Dr. W.A. Sinclair, Cornell Univ., Ithaca, N.Y.; Dr. T.A. Chen, Rutgers Univ., New Brunswick, N.J.; and Dr. C.W. Lee, North Dakota State Univ., Fargo, N.D., for providing experimental materials. We thank Wayne A. Sargent for helpful assistance, and Drs. S. Kianian and $\mathrm{P}$. McClean for reviewing the manuscript.

${ }^{1}$ To whom reprint requests should be sent: ZongMing (Max) Cheng, Dept. of Plant Sciences and Landscape Systems, Univ. of Tennessee, Knoxville, TN 37996-4500. Internet: zcheng@utk.edu C.W. Lee, North Dakota State Univ., Fargo. for phytoplasmal DNA extraction have been developed for PCR amplification (Gibb and Padovan, 1994; Green et al., 1999; Lee et al., 1993b; Levy et al., 1994), all require multiple steps or commercial kits. Several researchers have reported simplified DNA preparation procedures for detection or diagnosis of other organisms (Liu et al., 1995; Wang et al., 1993; Zhang and Goodwin, 1997). We report here adaptations of these simplified DNA preparation methods for PCR-based detection and diagnosis of phytoplasmas. They can significantly speed up the overall PCR process and reduce chemical and labor costs.

\section{Materials and Methods}

The plant materials, the associated phytoplasmas, and their sources for this research are listed in Table 1. Various methods were used to confirm the existence of the respective phytoplasmas (Table 1). Infected periwinkle plants containing various phytoplasmal strains were kept in the greenhouse and the phytoplasmas were maintained in them by grafting a branch from the diseased plant to a healthy one. Samples of green ash, carrot, and maize were from the various sources. Both phytoplasma-infected and noninfected plant samples were used. Very thin freehand cross-sections of leaf midribs, young shoots, or roots from the various plant materials were fixed in acetone for subsequent DNA extraction (Guo et al., 2000). Five methods were used to prepare the phytoplasma template DNA for testing.

For method 1, 10-20 fixed sections were ground in $20 \mu \mathrm{L} 0.3 \mathrm{~N} \mathrm{NaOH}$ with a tissue grinder (Kontes, $\mathrm{NJ}$ ) in a $1.5-\mathrm{mL}$ microtube. After clarification by full-speed centrifugation (Eppendorf centrifuge, model 5415D) for $30 \mathrm{~s}$, $2 \mu \mathrm{L}$ of extract was mixed with $48 \mu \mathrm{L}$ of 100 $\mathrm{mm}$ Tris ( $\mathrm{pH} 8.0)$. For the sonication method, 5-10 fixed sections were sonicated in $10 \mu \mathrm{L}$ water for $1 \mathrm{~min}$ (model \#2210, Bransonic Ultrasonic Cleaner; Branson, Danbury, Conn.). For the microwaving method, 5-10 fixed sections were microwaved in $10 \mu \mathrm{L}$ water for 5 min (model \#564.8844881, Kenmore Sensor Cook Microwave Oven; Sears, Roebuck

Table 1. Plant materials, associated phytoplasmas, sources, and confirmation methods.

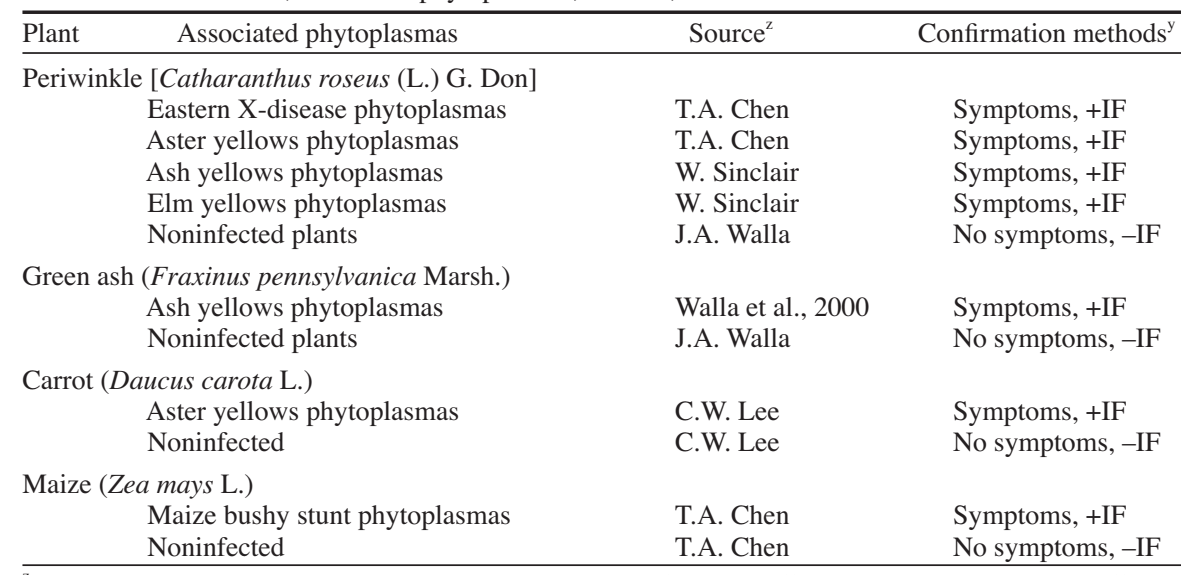

${ }^{\mathrm{z}}$ T.A. Chen, Rutgers Univ., New Brunswick, N.J.; W. Sinclair, Cornell Univ., Ithaca, N.Y.; J.A. Walla and

${ }^{\mathrm{y}}+$ and -IF: positive or negative immunofluorescence staining, respectively. 
and Co., Chicago). For the boiling method, 5-10 fixed sections were boiled in $10 \mu \mathrm{L} 0.3$ $\mathrm{N} \mathrm{NaOH}$ for $5 \mathrm{~min}$ and then neutralized with $10 \mu \mathrm{L} 0.3 \mathrm{~N} \mathrm{HCl}$. For the direct tissue method, 3-5 fixed sections were placed directly in the PCR reaction tube for amplification. A $1-\mu \mathrm{L}$ aliquot of solution from methods $1-4$ was used in each PCR reaction. DNA prepared by a more conventional method (Lee et al., 1993a) was used as the control. A universal phytoplasmaspecific primer pair (forward primer P16S3F: CGGGGTTTGTACACACCGCCCGTCA and reverse primer P235R:TCTTAGTGCCAAGGCATCCACTGTC), which amplifies the $16 \mathrm{~S} / 23 \mathrm{~S}$ ribosomal RNA spacer region, (Guo et al., 2000) was used in PCR amplification. The program for PCR amplification was denaturing for $1 \mathrm{~min}$ at $94{ }^{\circ} \mathrm{C}$, annealing for $2 \mathrm{~min}$ at $60{ }^{\circ} \mathrm{C}$ and extension for $3 \mathrm{~min}$ at 72 ${ }^{\circ} \mathrm{C}$, followed by a $10 \mathrm{~min}$ final extension at 72 ${ }^{\circ} \mathrm{C}$. The PCR reaction was performed in a final volume of $25 \mu \mathrm{L}$ containing $0.5 \%(\mathrm{v} / \mathrm{v})$ Triton $\mathrm{X}-100,1.5 \mathrm{~mm} \mathrm{MgCl}, 10 \mathrm{~mm}$ Tris- $\mathrm{HCl}(\mathrm{pH}$ 8.0), $200 \mu \mathrm{M}$ each of dNTPs, 0.4 pmol primers, and 0.625 units of Taq DNA polymerase (Promega Corp., Madison, Wis.) for 35 cycles in a thermocycler (RoboCycler Gradient 96, Stratagene, La Jolla, Calif.).

For the periwinkle plants infected by aster yellows phytoplasmas and the green ash plants infected by ash yellows phytoplasmas and their respective control plants, the DNA prepared by these five methods was also used in a standard two-step nested-PCR (Lee et al., 1993b). In the nested-PCR, the universal phytoplasma-specific primer pair was used first to determine whether the plant was infected with any phytoplasma, and then a second, phytoplasma group-specific primer pair was used to determine the specific phytoplasmal group.

All amplified products (10 $\mu \mathrm{L}$ each) were electrophoresed in a $1 \%$ agarose gel and visualized by UV light transillumination after staining with ethidium bromide.

\section{Results and Discussion}

All five methods provided phytoplasma DNA for successful PCR amplification from periwinkles infected with X-disease (shown in Fig. 1), aster yellows, ash yellows, and elm yellows phytoplasmas, carrot with aster yellows phytoplasmas, and maize with maize bushy stunt phytoplasmas, but not from any noninfected controls. However, the amount of amplified DNA was substantially lower using the direct tissue method. The grinding, microwaving and boiling, but not the sonication and direct tissue methods, provided phytoplasmal DNA for successful PCR amplification from green ash infected with ash yellows phytoplasmas (Fig. 2). The microwaving method resulted in a substantially weaker band than the grinding and boiling methods.

Results using nested-PCR consistently showed positive amplifications of DNA from infected, but not from noninfected, periwinkle and green ash plant materials (data not shown). Thus, the prepared DNA can be successfully used with various primer pairs to detect and diagnose various phytoplasmas.

HortScience, Vol. 38(6), October 2003

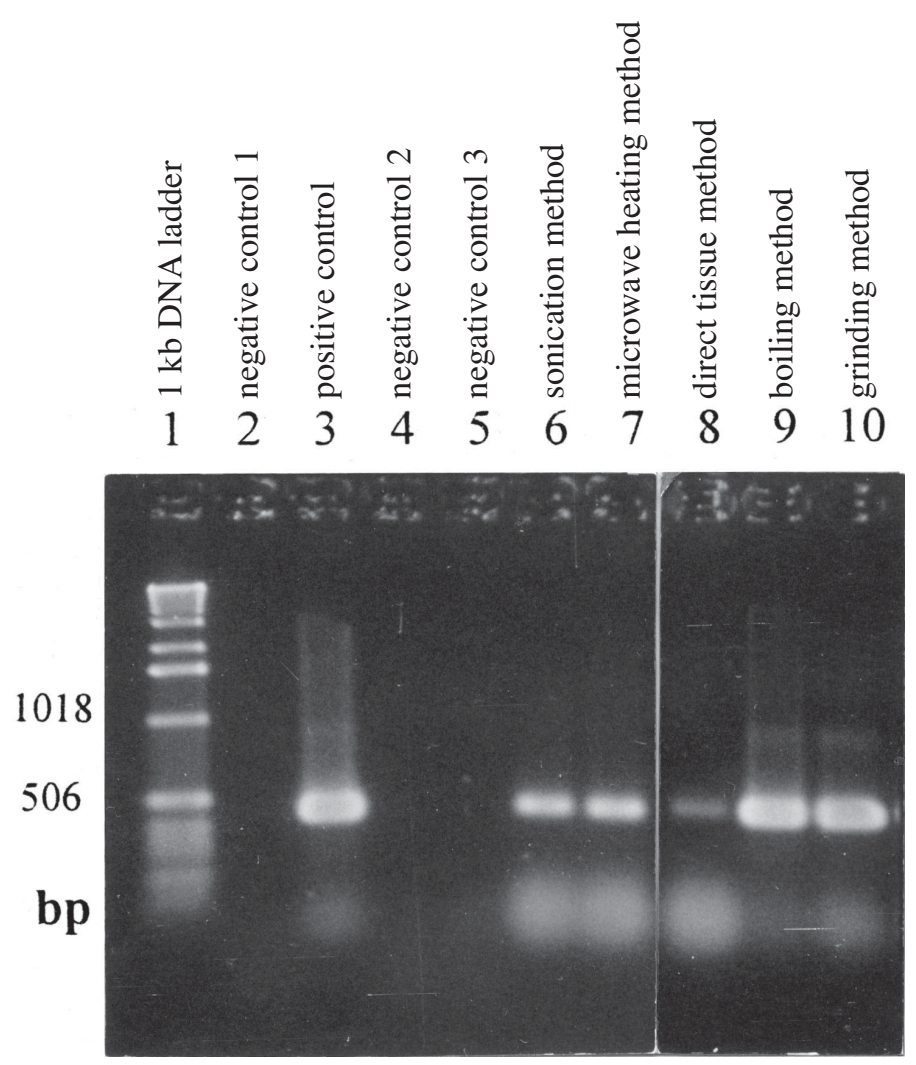

Fig. 1. Ethidium bromide-stained 1\% agarose gel of PCR-amplified products from template DNA prepared with different extraction methods from an X-disease phytoplasma-infected periwinkle. One kb DNA ladder was from Gibco BRL; the negative control 1 and the positive control were DNA prepared from noninfected and infected periwinkle using a conventional extraction method, respectively; negative control 2 and 3 were water and Tris- $\mathrm{HCl}$ buffer at $\mathrm{pH} 8.0$, respectively. Sonication, microwave heating, direct tissue PCR, boiling, and grinding, indicate the DNA template was prepared by the respective method described in the text. A band in lanes at the 440 bp level indicates that phytoplasma DNA was amplified (bands present in lanes 3 and 6-10).

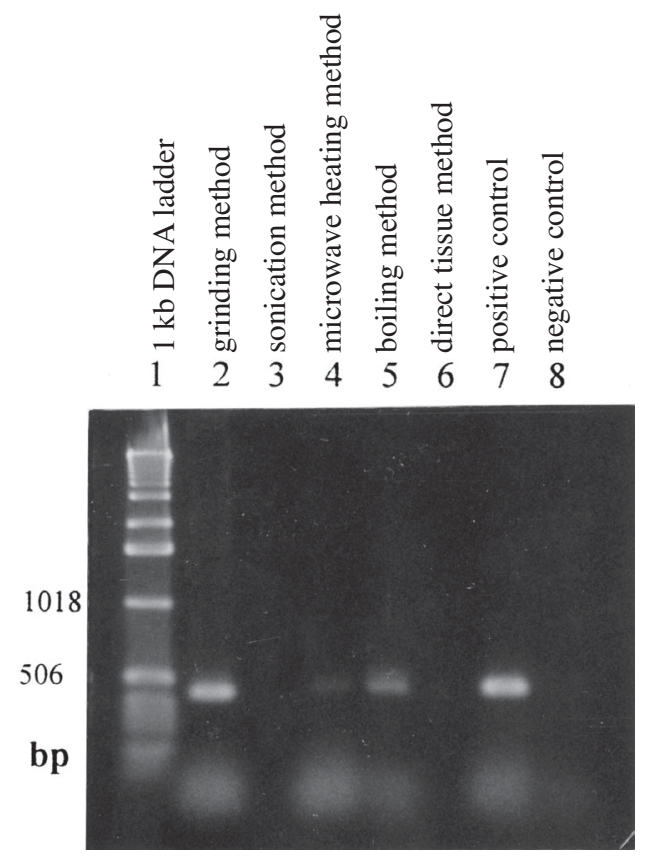

Fig. 2. Ethidium bromide-stained 1\% agarose gel of PCR-amplified products from template DNA prepared with different extraction methods from an ash yellows phytoplasma-infected green ash. One kb DNA ladder was from Gibco BRL; grinding, sonicating, microwave heating, boiling, and direct tissue methods indicate that DNA template was prepared by the respective method described in the text; positive and negative controls were DNA prepared using a conventional method from an ash yellows phytoplasmainfected and noninfected green ash plant, respectively. A band in lanes 2, 4, 5, 7 at the $440 \mathrm{bp}$ level indicates that phytoplasma DNA was amplified. 
Compared to published protocols of conventional preparation of phytoplasma DNA, the methods described here are much simpler. These processes apparently disrupt phytoplasma cells in the plant tissue sections and release phytoplasma DNA to the solution in less than $10 \mathrm{~min}$. The extracted/exposed DNA can be used directly as the template for the single-step PCR or two-step nested-PCR amplification. Because all five methods allowed positive amplifications of phytoplasma DNA from periwinkles, we recommend the direct tissue method for diagnosis of phytoplasmas in herbaceous plants because it is the simplest method. Among the methods that worked with the woody plant samples, we prefer the boiling method for phytoplasmal diagnosis with woody plants because grinding woody plant sections, which is difficult, and the microwaving method resulted in weaker amplification. These methods significantly simplify the laborious process of DNA preparation for PCR amplification, yet maintain the high sensitivity of traditional PCR methods, and therefore, can dramatically reduce the cost of the PCR-based diagnosis of phytoplasma diseases.

\section{Literature Cited}

Gibb, K. and A. Padovan. 1994. A DNA extraction method that allows reliable PCR amplification of MLO DNA from "difficult" plant host species. PCR Methods Appl. 4:56-58.

Green, M.J., D.A. Thompson, and D.J. MacKenzie. 1999. Easy and efficient DNA extraction from woody plants for the detection of phytoplasmas by polymerase chain reaction. Plant Dis. 83:482-485.

Guo, Y.H., Z.-M. Cheng, and J.A. Walla. 2000. Characterization of X-disease phytoplasmas in chokecherry from North Dakota by PCR-RFLP and sequence analysis of the rRNA gene region. Plant Dis. 84:1235-1240.

Kirkpatrick, B.C. 1989. Strategies for characterizing plant pathogenic mycoplasma-like organisms and their effects on plants, p. 241-293. In: T. Kosuge and E. Nester (eds.). Plant-microbe interactions, molecular and genetic perspectives. Vol. 3. McGraw-Hill Publ., New York.

Lee, I.-M., R.E. Davis, W.A. Sinclair, N.D. DeWitt and M. Conti. 1993a. Genetic relatedness of mycoplasmalike organisms detected in Ulmus spp. in the United States and Italy by means of DNA probes and polymerase chain reactions. Phytopathology 83:829-833.
Lee, I.-M., R.W. Hammond, R.E. Hammond, R.E. Davis, and D.E. Gundersen. 1993b. Universal amplification and analysis of pathogen $16 \mathrm{~S}$ rDNA for classification and identification of mycoplasmalike organisms. Phytopathology 83:834-842.

Levy, L., I.-M. Lee, and A. Hadidi. 1994. Simple and rapid preparation of infected plant tissue extracts for PCR amplification of virus, viroid, and MLO nucleic acids. J. Virol. Methods 49: 295-304.

Liu, Y.S., R.J.S. Thomas, and W.A. Philips. 1995. Single-step direct PCR amplification from solid tissues. Nucleic Acids Res. 23:1640.

Walla, J.A., W.R. Jacobi, N.A. Tisserat, M.O. Harrell, J.J. Ball, G.B. Neill, D.A. Reynard, Y.H. Guo, and L. Spiegel. 2000. Condition of green ash, incidence of ash yellows phytoplasmas, and their association in the Great Plains and Rocky Mountain regions of North America. Plant Dis. 84:268-274.

Wang, H., M. Qi, and A.J. Cutler. 1993. A simple method of preparing plant samples for PCR. Nucleic Acids Res. 21:4153-4154.

Zhang, S. and P.H. Goodwin. 1997. Rapid and sensitive detection of Xanthomonas fragariae by simple alkaline DNA extraction and the polymerase chain reaction. J. Phytopathol. 145:267-270. 